\title{
sciendo
}

RESEARCH PAPERS FACULTY OF MATERIALS

SCIENCE AND TECHNOLOGY IN TRNAVA

SLOVAK UNIVERSITY OF TECHNOLOGY

IN BRATISLAVA

2021, Volume 29, Number 48

DOI 10.2478/rput-2021-0012

\section{INITIATION PARAMETERS OF GRANULATED SYNTHETIC POLYMERS}

\author{
Peter RANTUCH ${ }^{1}$, Jozef MARTINKA ${ }^{1}$, Tomáš ŠTEFKO ${ }^{1}$, Igor WACHTER ${ }^{1}$ \\ ${ }^{1}$ SLOVAK UNIVERSITY OF TECHNOLOGY IN BRATISLAVA \\ FACULTY OF MATERIALS SCIENCE AND TECHNOLOGY IN TRNAVA \\ INSTITUTE OF INTEGRATED SAFETY \\ UlicA JÁNA BOTTU 2781/25, 91724 TRNAVA, SLOVAK REPUBLIC \\ e-mail: peter.rantuch@stuba.sk,jozef.martinka@stuba.sk, tomas.stefko@stuba.sk, \\ igor.wachter@stuba.sk \\ Received 28 April 2021, Accepted 26 May 2021, Published 20 July 2021
}

\begin{abstract}
Polymeric materials, which are currently very often used in various industries, are often transported and stored in the form of granules before processing. This method has several advantages, but in most studies the test samples are modified to different shapes and dimensions. This paper is therefore focused on the initiation of selected granular plastics. Samples of five polymeric materials were exposed to an external heat flux from $20 \mathrm{~kW} . \mathrm{m}^{-2}$ to $40 \mathrm{~kW} \cdot \mathrm{m}^{-2}$. A spark initiator was used to ignite the released gaseous products of thermal decomposition of the polymer sample. FTP (flow-time product) method was applied to the obtained parameter - time to ignition, from which other initiation parameters were determined. The critical heat flux was determined in the range of $5.0 \mathrm{~kW} . \mathrm{m}^{-2}-11.8 \mathrm{~kW} \cdot \mathrm{m}^{-2}$. Despite the relatively small thickness $(4 \mathrm{~mm})$, the samples behaved as thermally thick. During the measurement, thin surface layer melted, and the rest of the polymer remained in its original granulated form. Ignition temperatures were calculated according to the Stefan-Boltzmann's law between $273{ }^{\circ} \mathrm{C}-402{ }^{\circ} \mathrm{C}$.
\end{abstract}

\section{Keywords}

Critical heat flux, flow-time product, initiation, initiation temperature

\section{INTRODUCTION}

Global plastics production has been growing significantly in the last decades. The most produced plastics include the low and high density polyethylene and polypropylene [1]. About a half of the global plastics production accounts for Asia, followed by Europe. Of the European countries, Germany is the largest processor, and, together with Italy, France, Spain, the United Kingdom and Poland, they accounted for almost $70 \%$ of the European demand in 2017. Most of these plastics were used as packaging (39.7\%), in construction $(19.8 \%)$ and in the automotive industry (10.1\%) [2]. 
Synthetic polymers can differ quite significantly from one another in terms of their thermal decomposition. Table 1 shows the values for oxygen number (LOI), $5 \%$ weight loss temperature and residue at $700{ }^{\circ} \mathrm{C}$ in the nitrogen atmosphere.

\begin{tabular}{|c|c|c|c|}
\hline Polymer & LOI (\%) & $\begin{array}{c}\text { Temperature at } 5 \% \\
\text { mass loss }\left({ }^{\circ} \mathrm{C}\right)\end{array}$ & $\begin{array}{c}\text { Residue at } 700{ }^{\circ} \mathrm{C} \\
\left(\mathrm{N}_{2}\right)(\%)\end{array}$ \\
\hline PMMA & 17 & $\begin{array}{l}344\left(\mathrm{~N}_{2}\right) \\
305 \text { (air) }\end{array}$ & 0 \\
\hline PE & 18 & $\begin{array}{l}419\left(\mathrm{~N}_{2}\right) \\
315 \text { (air) }\end{array}$ & 0 \\
\hline $\mathbf{P P}$ & 18 & $\begin{array}{l}383\left(\mathrm{~N}_{2}\right) \\
247 \text { (air) }\end{array}$ & 0 \\
\hline ABS & 19 & $\begin{array}{l}399\left(\mathrm{~N}_{2}\right) \\
383 \text { (air) }\end{array}$ & 0 \\
\hline PBT & 20 & $\begin{array}{l}380\left(\mathrm{~N}_{2}\right) \\
379 \text { (air) }\end{array}$ & 4 \\
\hline PET & 21 & $\begin{array}{l}414\left(\mathrm{~N}_{2}\right) \\
398 \text { (air) }\end{array}$ & 11 \\
\hline PC & 27 & $\begin{array}{l}484\left(\mathrm{~N}_{2}\right) \\
444 \text { (air) }\end{array}$ & 22 \\
\hline
\end{tabular}

Thermal degradation of polyethylene occurs by random chain scission to form a small amount of monomer via free radicals [4]. Under a nitrogen atmosphere, the polyethylene degrades in one simple step, starting at about $350{ }^{\circ} \mathrm{C}$, while zero weight was measured at $490^{\circ} \mathrm{C}$. However, the degradation curve in the air contains some irregularities. The first step is well definable and starts at a temperature of about $220{ }^{\circ} \mathrm{C}$. The second one, relatively insignificant, occurs at $320^{\circ} \mathrm{C}$, while the third one occurs at $400{ }^{\circ} \mathrm{C}$ and continues to above 400 ${ }^{\circ} \mathrm{C}$. A slight weight gain at $200{ }^{\circ} \mathrm{C}$ was also measured when tested in the air [5]. Yu et al. state that the thermal decomposition of polyethylene in helium can be divided into three stages. The first one starts at $340.5^{\circ} \mathrm{C}$, the second one from $390{ }^{\circ} \mathrm{C}$ and the final one between $460{ }^{\circ} \mathrm{C}$ and $510^{\circ} \mathrm{C}[6]$. Based on the data of macro-thermogravimetric analysis, it is possible to divide the reaction of polyethylene granulate containing $30 \%$ talc into three temperature ranges [7]:

1. Area of a relative stability of the tested material

2. Area of the main thermal decomposition

3. Residue oxidation region

Degradation of polypropylene takes place by a chain radical reaction which leads to chain scission [4]. Its decomposition is described, for example, by Gersten et al. They report that it degrades in a single step in an inert environment with two endothermic peaks. The first occurs during its heating, starting at $430 \mathrm{~K}$ and continuing without weight loss up to $481 \mathrm{~K}$. The second peak corresponds to the decomposition reaction. [8] Pyrolysis begins at about $630 \mathrm{~K}$ and ends at about $740 \mathrm{~K}$ [9]. Also Peterson, Vyazovkin and Wight describe the decomposition of polypropylene in nitrogen in one step, stating a decomposition temperature range between $250{ }^{\circ} \mathrm{C}$ and $450{ }^{\circ} \mathrm{C}$. In the air, they initially observed a slight increase in weight at around $180{ }^{\circ} \mathrm{C}$. Thermal oxidation occurs mainly during the first step between $200{ }^{\circ} \mathrm{C}$ and $450{ }^{\circ} \mathrm{C}$. A smaller weight loss can then also be measured from $450{ }^{\circ} \mathrm{C}$ to $600{ }^{\circ} \mathrm{C}$ [5].

Polybutylene terephthalate can also be used at high temperatures. It degrades depending on temperature, environmental properties and photooxidation [4]. In nitrogen, at a heating rate of $10{ }^{\circ} \mathrm{C} \cdot \mathrm{min}^{-1}$, it decomposes in one step between $625 \mathrm{~K}$ and $700 \mathrm{~K}$. At a temperature of 
$1000 \mathrm{~K}$, the residue remains equal to $7 \%$ [9]. Arii and Masuda report a temperature range from $300{ }^{\circ} \mathrm{C}$ to $450{ }^{\circ} \mathrm{C}$ at a heating rate of $5{ }^{\circ} \mathrm{C} \cdot \mathrm{min}^{-1}$, but its thermal decomposition is influenced by the partial pressure of water vapour in the atmosphere [10]. In contrast to an inert atmosphere, when tested in oxygen, polybutylene terephthalate decomposes in two stages. The first one is practically the same as in nitrogen, and the second one is caused by the decomposition of the carbon residue in the presence of oxygen [11].

Unlike the thermo-oxidative degradation of other polymers, in the case of polyethylene terephthalate and polybutylene terephthalate, thermal degradation plays an important role especially at the beginning, but polyethylene terephthalate is generally more stable than polybutylene terephthalate [4]. Its thermal decomposition in nitrogen is described by Dhahak et al. as a degradation in one step starting at $350{ }^{\circ} \mathrm{C}$ [12]. The initial degradation temperature of polyethylene terephthalate is strongly dependent on the atmosphere in which thermal decomposition occurs. It starts in the air at a heating rate of $10{ }^{\circ} \mathrm{C} \cdot \mathrm{min}^{-1}$ from $305^{\circ} \mathrm{C}$, and in nitrogen from $380{ }^{\circ} \mathrm{C}$. The degradation itself is then more significant in the air [13]. Meliflex is a thermoplastic polyolefin used in healthcare [14]. It is transparent, flexible and exhibits high UV resistance [15].

Before processing, polymeric materials are often transported and stored in the form of granules. Form of materials plays an important role during initiation phase of fire. This paper is therefore focused on the initiation parameters of plastics in granular forms.

\section{MATERIALS AND METHODOLOGY OF EXPERIMENT}

Samples of five polymers in the form of granules were investigated. Two samples were black, two white and one was milky. The samples were marked P1 - P5. The first four ones were of a known composition, while sample P5 was made of an unspecified type of Meliflex plastics (Table 2).

\begin{tabular}{|l|l|c|}
\hline Table 2 Characterization of samples of polymer granules \\
\hline $\begin{array}{l}\text { Sample } \\
\text { marking }\end{array}$ & Composition & $\begin{array}{c}\text { Bulk density } \\
\left(\mathbf{g . c m}^{-3}\right)\end{array}$ \\
\hline P1 & Polypropylene, talc 20\% & 0.64 \\
\hline P2 & $\begin{array}{l}\text { Polypropylene 28 \%, polybutylene terephthalate 25 \%, } \\
\text { glass fibres 45 \% }\end{array}$ & 0.95 \\
\hline P3 & Polyethylene terephthalate & 0.90 \\
\hline P4 & Polybutylene terephthalate & 0.75 \\
\hline P5 & Meliflex & 0.59 \\
\hline
\end{tabular}

A schematic representation of the measurement is shown in Figure 1. The granules of the measured polymers were poured into an aluminium cone bowl with a free surface area of $265.9 \mathrm{~cm}^{2}$ and a height of $4 \mathrm{~mm}(3)$. The cones were placed in a sample holder (1), underlain by the mineral wool insulation (2). The external heat flux to the free surface of the samples was provided by a cone heater (5), while a spark initiator (4) located $13 \pm 2 \mathrm{~mm}$ above the centre of the sample surface was used to initiate the flame combustion of the gaseous decomposition products. The thermal decomposition products were sucked out by the suction bell (6) at a flow rate of $0.024 \pm 0.002 \mathrm{~m}^{3} . \mathrm{s}^{-1}$. The ambient air temperature during the measurements was from $28{ }^{\circ} \mathrm{C}$ to $30{ }^{\circ} \mathrm{C}$, its humidity was between $36 \%$ and $46 \%$, and the atmospheric pressure was $99.94 \mathrm{kPa}-100.20 \mathrm{kPa}$. 


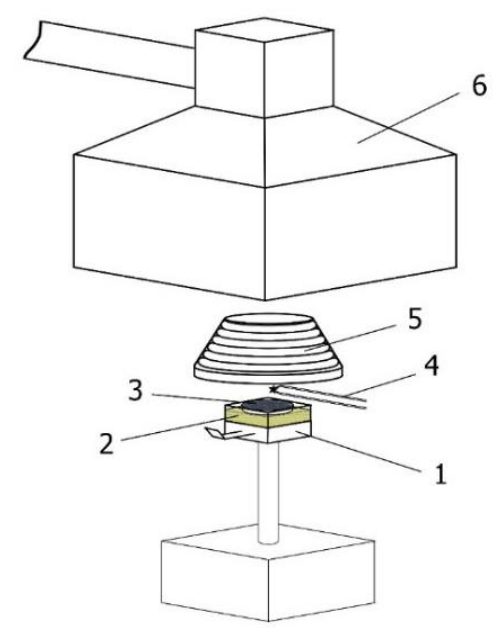

Figure 1 Measurement scheme: 1 - sample holder; 2 - mineral wool insulation; 3 - sample pan; 4 - spark ignitor; 5 - cone heater; 6 - exhaust hood

Three characteristics were used to describe the initiation: flux-time product (FTP), critical heat flux $\left(\mathrm{q}_{\mathrm{cr}}\right)$ and initiation temperature $\left(\mathrm{T}_{\mathrm{ig}}\right)$.

FTP is used to predict the initiation of combustible material. When its limit value is exceeded, the material ignites. It is possible to use the following relation to calculate FTP [16]:

$$
F T P=t_{i g} q_{e f}^{n},
$$

where $t_{\mathrm{ig}}$ is time to initiation, $\mathrm{q}_{\mathrm{ef}}$ is effective heat flux and $\mathrm{n}$ is empirical constant called index of flux-time product. Then:

$$
q_{e f}=\left(q-q_{c r}\right)
$$

where $\mathrm{q}$ is heat flux.

The (1) and (2) relationships can then be mathematically adjusted to the following form [16]:

$$
q=\frac{(F T P)^{\frac{1}{n}}}{t_{i g^{\frac{1}{n}}}}+q_{c r} .
$$

Although the FTP concept was designed to determine the time to initiation in thermally sealed systems, it can also be useful for open systems [17]. Shields, Silcock and Murray state that, for open systems, the flux-time product index is higher, at most equal to one [18].

The initiation temperature can be calculated based on the Stefan-Boltzmann's law. When introducing the simplification that the test sample will behave as a perfectly black body, the emissivity value will be equal to one, and therefore the relation can be used:

$$
T_{i g}=\left(\frac{q_{c r}}{\sigma}\right)^{\frac{1}{4}}-273,15,
$$

where $\sigma$ is the Stefan-Boltzmann's constant.

Thickness of the sample is assessed in terms of initiation parameters, by so-called thermal thickness $(\delta \mathrm{P})$. If the depth of penetration of heat waves into the material is less than its physical thickness, then it is a thermally thick material in which further increase in physical thickness does not affect the time to initiation under the given conditions. However, for thinner samples, the effect of thickness on time to initiation can be expected, while the substrate on which the sample is placed can also play an important role [18].

The thermal thickness of the material thus depends on its physical thickness and the depth of penetration of heat waves inside the sample. In general, thermal thickness of a material is determined based on the relationship [20]: 


$$
\delta_{P}=A \sqrt{\frac{\lambda t_{i g}}{\rho C_{p}}},
$$

where $A$ is constant, $\lambda$ is thermal conductivity, $\rho$ is density, and $C_{p}$ is specific heat capacity.

The depth of penetration of heat waves into the polymer can be calculated as [19]:

$$
\delta_{P}=0,14 \frac{\rho}{q} .
$$

However, equation (6) applies to the autoignition and not to pilot ignition of the polymeric material. Another possibility to determine the thermal thickness is to compare the determining coefficients for the dependences compiled according to equation (3) for different $\mathrm{n}$.

Based on the work of Mikkol and Wichman, it can be stated that thermally thin materials have $n=1$ and thermally thick materials $n=2[21]$.

\section{ATTAINED RESULTS AND DISCUSSION}

From the obtained time to initiation values, linear dependences of the $\mathrm{n}^{\text {th }}$ root of the time to initiation and the external heat flux were constructed for $n=1.0-2.0$, in steps of 0.1 . Subsequently, the dependence with the highest determination coefficient was selected for each sample. Graphs of these functions are shown in Figure 2.

Table 3 Comparison of the initiation characteristics of the measured granules

\begin{tabular}{|c|c|c|c|c|c|c|}
\hline Sample & $\begin{array}{l}\text { n } \\
(-)\end{array}$ & $\begin{array}{l}\mathbf{R}^{2} \\
(-)\end{array}$ & $\begin{array}{c}\mathbf{q c r} \\
\left(\mathrm{kW} \cdot \mathrm{m}^{-2}\right)\end{array}$ & $\begin{array}{c}\text { FTP } \\
\left(\mathrm{s} . \mathrm{kWn} \cdot \mathrm{m}^{-2 \mathrm{n}}\right)\end{array}$ & $\begin{array}{c}\mathbf{T}_{\mathbf{i g}} \\
\left({ }^{\circ} \mathrm{C}\right)\end{array}$ & Source \\
\hline Polyethylene & - & - & $\begin{array}{l}13^{\mathrm{a}} \\
15^{\mathrm{b}}\end{array}$ & - & $\begin{array}{l}363^{\mathrm{a}} \\
380^{\mathrm{b}}\end{array}$ & [22] \\
\hline Polypropylene & - & - & $\begin{array}{c}11^{\mathrm{a}} \\
11-15^{\mathrm{b}}\end{array}$ & - & $\begin{array}{l}338^{\mathrm{a}} \\
330- \\
370^{\mathrm{b}}\end{array}$ & [22] \\
\hline Polybutyl terephthalate & - & - & $\begin{array}{c}8^{\mathrm{a}} \\
10-20^{\mathrm{b}}\end{array}$ & - & $\begin{array}{l}213^{\mathrm{a}} \\
382^{\mathrm{b}}\end{array}$ & [22] \\
\hline $\begin{array}{l}\text { Polyethylene } \\
\text { terephthalate }\end{array}$ & - & - & $\begin{array}{c}12^{\mathrm{a}} \\
10-19^{\mathrm{b}}\end{array}$ & - & $\begin{array}{l}324^{\mathrm{a}} \\
407^{\mathrm{b}}\end{array}$ & [22] \\
\hline Polyethylene & $2.0^{\mathrm{c}}$ & $0.9540^{\mathrm{c}}$ & $10.7^{\mathrm{c}}$ & $49018^{c}$ & $363^{\mathrm{b}}$ & [23] \\
\hline Polypropylene & $1.9^{\mathrm{c}}$ & $0.9979^{\mathrm{c}}$ & $4.3^{\mathrm{c}}$ & $45846^{\mathrm{c}}$ & $334^{\mathrm{b}}$ & [23] \\
\hline Polypropylene & $1.3^{\mathrm{c}}$ & $0.9986^{\mathrm{c}}$ & $8.0^{\mathrm{c}}$ & $3724^{\mathrm{c}}$ & $\begin{array}{l}314- \\
332^{b}\end{array}$ & [24] \\
\hline Polyethylene & $1.2^{\mathrm{c}}$ & $0.9965^{\mathrm{c}}$ & $15.8^{\mathrm{c}}$ & $4976^{\mathrm{c}}$ & $454^{\mathrm{c}}$ & [25] \\
\hline Polypropylene & $1.1^{\mathrm{c}}$ & $0.9927^{\mathrm{c}}$ & $10.7^{\mathrm{c}}$ & $2526^{c}$ & $\begin{array}{l}332- \\
345^{\mathrm{b}} \\
386^{\mathrm{c}}\end{array}$ & [25] \\
\hline $\begin{array}{l}\text { Acrylonitrile-butadiene- } \\
\text { styrene }\end{array}$ & $1.8^{\mathrm{a}}$ & - & $7.1^{\mathrm{a}}$ & $19241^{\mathrm{a}}$ & $322^{c}$ & [16] \\
\hline P1 & 1.9 & 0.9977 & 5.0 & 20239 & 273 & \\
\hline $\mathbf{P 2}$ & 2.0 & 0.9704 & 11.8 & 24149 & 402 & \\
\hline P3 & 2.0 & 0.9831 & 6.3 & 94470 & 304 & \\
\hline P4 & 2.0 & 0.9854 & 5.9 & 72442 & 295 & \\
\hline P5 & 1.4 & 0.9962 & 10.0 & 3157 & 375 & \\
\hline
\end{tabular}
with the values reported for polymers in the literature 
P1

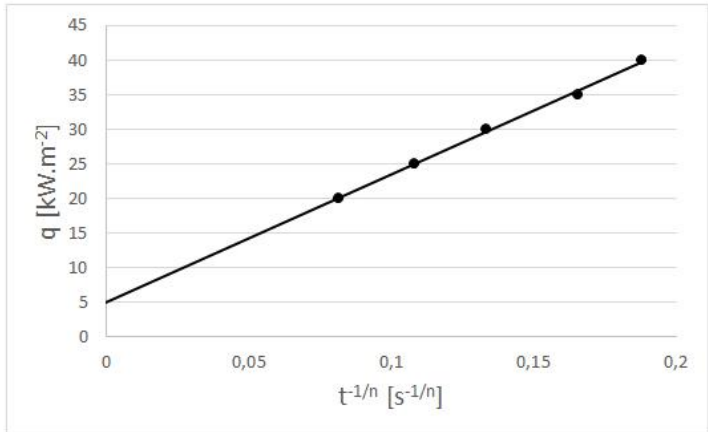

P3

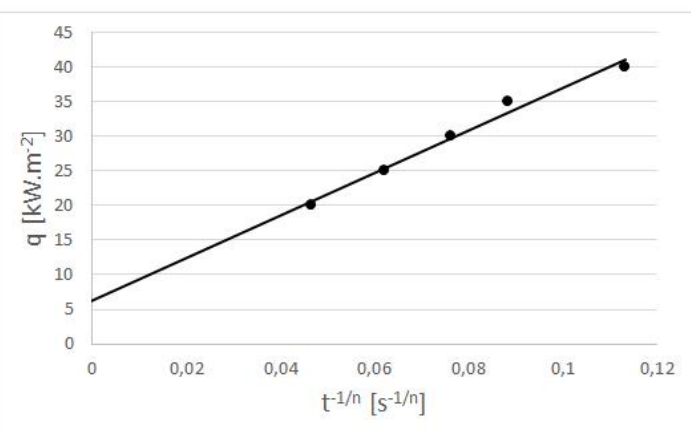

P2

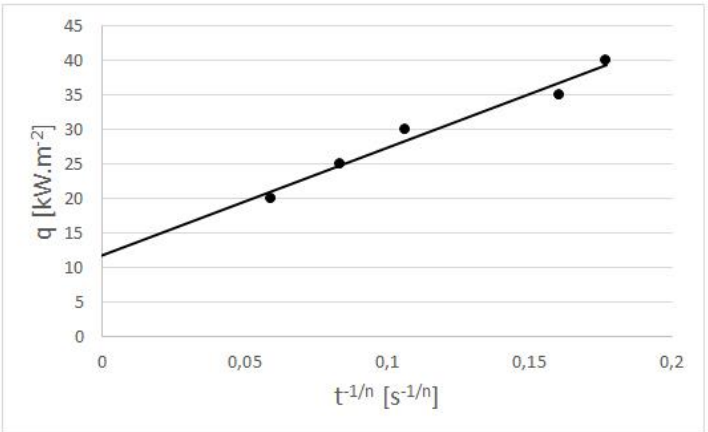

P4

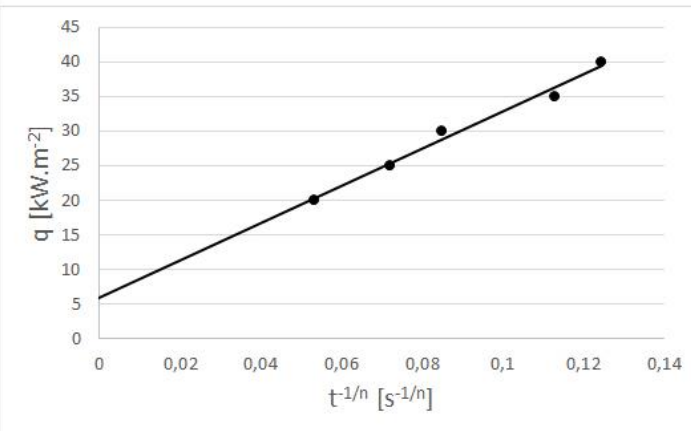

P5

Figure 2 Dependences of the external heat flux and the corresponding power of time to the initiation of measured samples

Critical heat flux and a flux-time product were determined for each sample from the resulting trend line equations. Subsequently, the critical heat flux was used to calculate the initiation temperature according to Equation (4). Their values, together with the relevant coefficients $\mathrm{n}$ and the determination coefficients are shown below Table 3 .

The lowest critical heat flux was determined for granulate P1 and the highest for granulate $\mathrm{P} 2$. Their values were $5.0 \mathrm{~kW} . \mathrm{m}^{-2}$ and $11.8 \mathrm{~kW} . \mathrm{m}^{-2}$ respectively, which is similar to the values determined from measurements by other authors (Table 3). The variance of FTP values is significantly wider, which is due to its dependence on the exponent $\mathrm{n}$. The lowest value was reached by the sample P5 with $n=1.4$, the highest by the samples P2, P3 and P4 with $n=2$. Initiation temperatures ranged from $273{ }^{\circ} \mathrm{C}$ to $402{ }^{\circ} \mathrm{C}$. These values should be considered as indicative and slightly lower than they would be during direct measurement, as the emissivity 
in the molten state was not known. Nevertheless, these values are similar to those given by other authors.

Equation (6) was used to determine the thermal thickness of the granules, substituting the bulk density of the granulate instead of the density of the polymer itself. The results are shown in Table 4. The heat flux for which the heat thickness of the materials was calculated is given by a numerical value in the index. It is obvious that at a heat flux of $20 \mathrm{~kW} . \mathrm{m}^{-2}$ the real thickness of the measured samples is greater than the limit for thermally thin samples. When heat fluxes of $35 \mathrm{~kW} \cdot \mathrm{m}^{-2}$ and $40 \mathrm{~kW} \cdot \mathrm{m}^{-2}$ were used, it was already possible to consider all samples as thermally thin. From this point of view, the thickness of the sample during the measurement is at the interface of thermally thin and thermally coarse materials at the used heat fluxes. However, these values refer to the autoignition of the sample and not to its pilot ignition. For this reason, it is more advantageous to determine their thermal thickness based on the dependences in Figure 2.

\begin{tabular}{|l|c|c|c|c|c|}
\hline Table 4 Thermal thickness of measured granules for used heat fluxes \\
\hline Sample & $\boldsymbol{\delta P 2 0}^{\mathbf{a}}(\mathbf{m m})$ & $\boldsymbol{\delta P 2 5}^{\mathbf{b}}(\mathbf{m m})$ & $\boldsymbol{\delta P 3 0}^{\mathbf{c}}(\mathbf{m m})$ & $\boldsymbol{\delta} \mathbf{3} 5^{\mathbf{d}}(\mathbf{m m})$ & $\boldsymbol{\delta}_{\mathbf{P 4 0}} \mathbf{e}^{\mathbf{e}}(\mathbf{m m})$ \\
\hline P1 & 4.5 & 3.6 & 3.0 & 2.6 & 2.2 \\
\hline P2 & 6.6 & 5.3 & 4.4 & 3.8 & 3.3 \\
\hline P3 & 6.3 & 5.1 & 4.2 & 3.6 & 3.2 \\
\hline P4 & 5.2 & 4.2 & 3.5 & 3.0 & 2.6 \\
\hline P5 & 4.2 & 3.3 & 2.8 & 2.4 & 2.1 \\
\hline
\end{tabular}

${ }^{\mathrm{a}}$ external heat flux of $20 \mathrm{~kW} \cdot \mathrm{m}^{-2}$

${ }^{b}$ external heat flux of $25 \mathrm{~kW} \cdot \mathrm{m}^{-2}$

${ }^{c}$ external heat flux of $30 \mathrm{~kW} \cdot \mathrm{m}^{-2}$

${ }^{\mathrm{d}}$ external heat flux of $35 \mathrm{~kW} \cdot \mathrm{m}^{-2}$

e external heat flux of $40 \mathrm{~kW} \cdot \mathrm{m}^{-2}$

The values of the coefficient $\mathrm{n}$ indicate that most samples behaved as thermally thick rather than thermally thin materials. Given the physical thickness of the samples, this is quite a surprising finding. Since all samples melted owing to the elevated temperature, one sample was extinguished and cooled immediately after initiation. Three layers can be observed in its crosssection in Figure 3:

1. A thin layer of degraded material on the surface of the sample

2. A layer of molten material

3. A layer of original material

It is clear from this composition that the temperature profile in the cross section of the sample at the time of initiation was not constant. Thus, the temperature inside the sample varied quite significantly and, despite the small physical thickness, it could not be a thermally thin material. The probable explanation is its form. The granulate is composed of grains between which there are spaces filled with air. Such a structure has a significantly higher insulating capacity than the compact polymer and thus impairs the penetration of heat waves into the interior of the sample. 


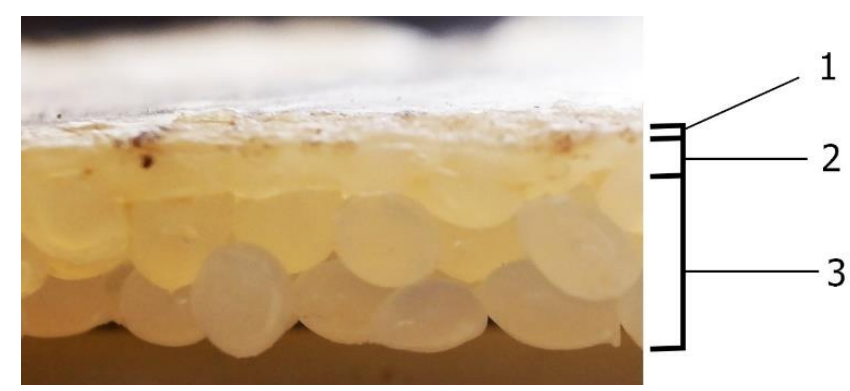

Figure 3 Detail of the sample after measurement: 1 - layer of degraded material; 2 - layer of molten material; 3 - layer of raw material

\section{CONCLUSION}

The estimated time to initiation of combustible materials can be calculated using the critical heat flux and flux-time product. Both of these initiation characteristics can be obtained by measuring the initiation time at different external heat fluxes. For the purposes of this paper, five polymeric materials in the form of granules were exposed to these heat fluxes. The highest critical heat flux was determined on the basis of the FTP method for a polymer containing a mixture of polyethylene, polybutylene terephthalate and glass fibers $-11.8 \mathrm{~kW} \cdot \mathrm{m}^{-2}$. This material can be considered the safest in terms of fire protection. In contrast, the lowest critical heat flux $\left(5.0 \mathrm{~kW} . \mathrm{m}^{-2}\right)$ was calculated for a polypropylene-based polymer.

FTP ranged from 3157 to 94470 . This significant variance is caused by the exponent $n$, which characterizes the thermal thickness of the sample and varied with the individual granules. The samples behaved as thermally thick material during testing, which is probably due to air gaps between the polymer granules. Under thermal loading, the upper layer of material melts and the layers below it remain in their original form due to insulation.

\section{Acknowledgement}

This research was supported by the Agency for the Support of Research and Development on the basis of Contract No. APVV-16-022.

\section{References}

[1] GEYER, R., JAMBECK, J. R., LAW, K. L. 2017. Production, use, and fate of all plastics ever made. Supplementary materials. Science advances, 3(7), e1700782. ISSN 2375-2548.

[2] PLASTICS EUROPE. 2018. Plastics - the facts 2018, An analysis of European plastics production, demand and waste data. 60.

[3] JANG, B. N., JUNG, I., CHOI, J. 2009. Study of a novel halogen- free flame retardant system through TGA and structure analysis of polymers. Journal of applied polymer science, 112(5), 6692675. ISSN 1097-4628.

[4] PIELICHOWSKI, K., NJUGUNA, J. 2008. Thermal degradation of polymeric materials. $1^{\text {st }}$ ed. iSmithers Rapra Publishing, 2008. 316 p. ISBN 1-85957-498-X.

[5] PETERSON, J. D., VYAZOVKIN, S., WIGHT, C. A. 2001. Kinetics of the thermal and thermooxidative degradation of polystyrene, polyethylene and poly (propylene). Macromolecular Chemistry and Physics, 202(6), 775-784. ISSN 1521-3935.

[6] YU, L. L., ZHAO, C. Z., LIU, S. J., DI, M. 2013. Alkane Influence of Combustion Products in Polyethylene and Gasoline. Procedia Engineering, 52, 566-570. 1877-7058.

[7] RANTUCH, P. 2015. Aktivačná energia termooxidácie polyetylénového granulátu (Activation energy of thermooxidation of polyethylene granulate). In: Integrovaná bezpečnost' (Integrated safety). Slovak Republic, pp. 55-63. ISBN 978-80-89753-04-8. 
[8] GERSTEN, J., FAINBERG, V., HETSRONI, G., SHINDLER, Y. 2000. Kinetic study of the thermal decomposition of polypropylene, oil shale, and their mixture. Fuel, 79(13), 1679-1686. ISSN 0016-2361.

[9] GALLO, E., BRAUN, U., SCHARTEL, B., RUSSO, P., ACIERNO, D. 2009. Halogen-free flame retarded poly (butylene terephthalate) (PBT) using metal oxides/PBT nanocomposites in combination with aluminium phosphinate. Polymer Degradation and Stability, 94(8), 1245-1253. ISSN 0141-3910.

[10] ARII, T., MASUDA, Y. 2004. The effect of humidity on thermal decomposition of terephthalate polyester. Journal of analytical and applied pyrolysis, 71(2), 525-536. ISSN: 0165-2370.

[11] BIAN, J., LIN, H. L., HE, F. X., WANG, L., WEI, X. W., CHANG, I. T., SANCAKTAR, E. 2013. Processing and assessment of high-performance poly (butylene terephthalate) nanocomposites reinforced with microwave exfoliated graphite oxide nanosheets, European polymer journal, 49(6), 1406-1423. ISSN 0014-3057.

[12] DHAHAK, A., HILD, G., ROUAUD, M., MAUVIEL, G., BURKLE-VITZTHUM, V. 2019. Slow pyrolysis of polyethylene terephthalate: Online monitoring of gas production and quantitative analysis of waxy products. Journal of Analytical and Applied Pyrolysis, 142, 104664. ISSN 01652370.

[13] JABARIN, S. A., LOFGREN, E. A. 1984. Thermal stability of polyethylene terephthalate, Polymer Engineering \& Science, 24(13), 1056-1063. ISSN 1548-2634.

[14] MELITEK. Meliflex - dedicated range of compounds for healthcare

[15] KILGOUR, K. G. 2016. Elevation: Folding the Interior. Master theses. Victoria University of Welington, 2016. $156 \mathrm{p}$.

[16] BAKER, G., COLLIER, P., WADE, C., SPEARPOINT, M., FLEISCHMANN, C. M., FRANK, K., SAZEGARA, S. 2013. A comparison of a priori modelling predictions with experimental results to validate a design fire generator submodel. In: $13^{\text {th }}$ Fire and Materials conference. San Francisco; pp. 449-460.

[17] SILCOCK, G. W. H., SHIELDS, T. J. 1995. A protocol for analysis of time-to-ignition data from bench scale tests, Fire Safety Journal, 24(1), 75-95. ISSN 0379-7112.

[18] SHIELDS, T. J., SILCOCK, G. W., MURRAY, J. J. 1994. Evaluating ignition data using the flux time product, Fire and Materials, 18(4), 243-254. ISSN 1099-1018.

[19] SHI, L., CHEW, M. Y. L. 2013. Fire behaviors of polymers under autoignition conditions in a cone calorimeter, Fire Safety Journal, 61, 243-253. ISSN 0379-7112.

[20] CHEN, R., LU, S., LI, C., DING, Y., ZHANG, B., LO, S. 2016. Correlation analysis of heat flux and cone calorimeter test data of commercial flame-retardant ethylene-propylene-diene monomer (EPDM) rubber, Journal of Thermal Analysis and Calorimetry, 123(1), 545-556. ISSN 1588-2926.

[21] MIKKOLA, E., WICHMAN, I. S. 1989. On the thermal ignition of combustible materials, Fire and Materials, 14(3), 87-96. ISSN 1099-1018.

[22] LYON, R. E., QUINTIERE, J. G. 2007. Criteria for piloted ignition of combustible solids, Combustion and Flame, 151(4), 551-559. ISSN 0010-2180.

[23] THOMSON, H. E., DRYSDALE, D. D. 1987. Flammability of plastics I: ignition temperatures, Fire and Materials, 11(4), 163-172. ISSN 1099-1018.

[24] DRYSDALE, D. D., THOMSON H. E. 1994. The Ignitability of Flame Retarded Plastics, Fire Safety Science, 4, 195-204. ISSN 18174299.

[25] THOMSON H. E., DRYSDALE D. D. A BEYLER C. L. 1988. An experimental evaluation of critical surface temperature as a criterion for piloted ignition of solid fuels, Fire Safety Journal, 13(2-3), 185-196. ISSN 0379-7112.

\section{ORCID}

Peter Rantuch

Jozef Martinka

Tomáš Štefko

Igor Wachter
0000-0001-5826-8323

0000-0002-0060-5785

0000-0002-3975-6775

0000-0003-0691-0462 